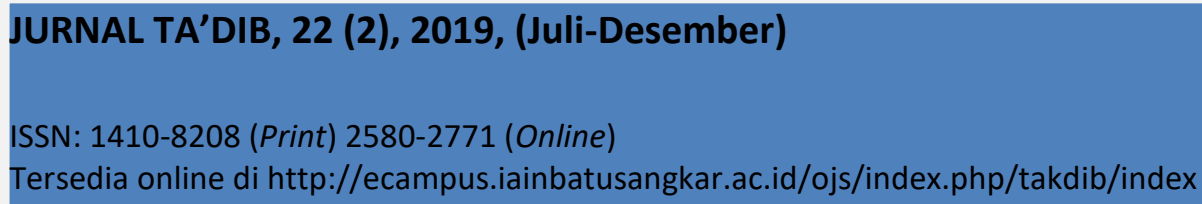

\title{
Antara Tradisionalis dan Modernis: Pemikiran Pendidikan K.H. Ahmad Dahlan
}

\author{
Kasmuri Selamat*) \\ Institut Agama Islam Negeri Batusangkar, \\ Sumatera Barat, Indonesia \\ E-mail: kasmuriselamat31@gmail.com
}

\begin{abstract}
The early twentieth century Islamic education was not firmly looking into the aspect of knowledge. What the Islamic world have seen for centuries is the practice of separation between faith, knowledge and intellectualism. In other words, the education system professed a dualism which was without precedence in the Islamic world. Both of the education systems had their own weakness. Under the western education systems the Islamic World practiced a type of education which more emphasized the aspects of intellectualism, which is more towards materialism rather than faith. While the other which is more traditional, developed the aspect of faith and eternity. The Islamic faith suggest its followers to have such belief that if great efforts are made, they will gain bliss and happiness in life and in hereafter. These orientations and basic foundations are also being practiced in the Islamic World. Fulfilling the above aspiration, K.H. Ahmad Dahlan (1923 AD) and his Muhammadiyah organization moved ahead aiming their goals at developing and innovating the education system of Indonesia in particular. He integrated the teaching of Islam and its culture, with the inclusion of the acquisition of knowledge according to the Islamic way.
\end{abstract}

Keywords: K.H. Ahmad Dahlan, Education systems, Islamic World.

\section{PENDAHULUAN}

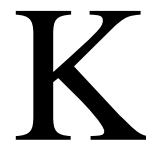

.H. Ahmad Dahlan dilahirkan pada tahun 1868 dan meninggal tahun 1923, merupakan seorang tokoh yang sangat peka terhadap penderitaan masyarakat. K.H. Ahmad Dahlan meyakini pendidikan Islam merupakan hal yang paling pokok dalam menentang penjajah. Di antara pokok pikirannya ialah; "kunci persoalan kualitas hidup dan kemajuan umat Islam ialah pemahaman terhadap berbagai ilmu pengetahuan yang sedang berkembang dalam tata kehidupan masyarakat (Mulkhan, 1990)."

Pada tahun 1908-1909, K.H. Ahmad Dahlan mendirikan sekolah yang pertama secara formal, yaitu Madrasah Ibtidaiyah di ruang tamu rumahnya yang relatif sempit yaitu berukuran 2.5 x $6 \mathrm{~m}^{2}$ (Mulkhan, 1990). Sekolah tersebut dilaksanakan secara modern dengan menggunakan metode dan kurikulum baru; antara lain mengajarkan berbagai ilmu pengetahuan yang sedang berkembang pada awal abad 20.

Ada dua faktor yang menjadi gagasan dalam usaha yang dilakukan oleh K.H. Ahmad Dahlan dalam mendirikan sekolah ketika itu. Pertama, faktor sejarah, kedua, faktor yang timbul akibat adanya perkembangan dalam diri umat Islam. Ditinjau dari faktor sejarah pada mulanya sistem pendidikan dirancang untuk kepentingan yang sangat pragmatis dan dengan cara yang sangat sederhana. Dilihat dari sudut pandangan ini maka pendidikan yang didirikan oleh K.H. Ahmad Dahlan 
secara sederhana dapat dikatakan sebagai salah satu usaha untuk keluar dari budaya pendidikan model pondok pesantren.

Menurut Yusuf \& Dkk (1985), usaha yang dilakukan K.H. Ahmad Dahlan itu sangat besar artinya, sebagai jawaban terhadap perkembangan dalam diri umat Islam pada saat itu. Perkembangan intelektual umat Islam Indonesia telah dikungkung oleh penjajah selama tiga setengah abad. Hal tersebut ditandai oleh beberapa gejala: kerusakan akidah dibidang kepercayaan agama (itikad); kebekuan dalam bidang hukum fiqh; kemunduran dalam bidang pendidikan Islam; dan kemajuan zending Kristen dan misi katolik. Dari gejala-gejala yang dapat menghilangkan kemurnian nilai Islam tersebut telah menjadi motivasi terhadap K.H. Ahmad Dahlan untuk membersihkan Islam dari pengaruh-pengaruh dan kebiasaan-kebiasaan bukan Islam; memformulasikan kembali doktrin Islam menurut alam pikiran modern; reformasi ajaran dan pendidikan Islam; membentengi Islam dari pengaruh dan serangan luar; serta melepaskan Indonesia dari belenggu penjajah (Yusuf \& Dkk, 1985).

Pada dasarnya cita-cita pendidikan K.H. Ahmad Dahlan meliputi tiga aspek utama, yaitu: 1) perbaikan akhlak, 'alim dan beragama, 2) Luas pandangan, pandai dalam ilmu-ilmu umum atau ilmu alam (Haviz et al., 2018; Umar et al., 2017; Umar et al., 2014), dan 3) bersedia berjuang untuk kemajuan masyarakat (Yusuf \& Dkk, 1985). K.H. Ahmad Dahlan melihat bahwa pendidikan merupakan kunci untuk melakukan berbagai perintah agama. Mengingat ketika itu sistem pendidikan kolonial Belanda masih menjadi yang terbaik, maka jalan termudah yang dipilih adalah dengan cara memformulasi sistem tersebut, lalu disempurnakan dengan menambah nilai-nilai agama di dalamnya. Umat Islam dijauhkan dari pemahaman mistis melainkan diarahkan untuk menghadapi dunia secara realistik, di mana muslim yang baik harus memberi banyak manfaat kepada diri sendiri maupun untuk orang lain melalui karya-karyanya (Yusuf \& Dkk, 1985). Dari sini dapat terlihat bahwa K.H. Ahmad Dahlan sangat objektif dalam menerima kebudayaan asing, yakni sistem pendidikan Barat.

Tujuan pendidikan yang dilaksanakan K.H. Ahmad Dahlan di atas untuk mengatasi sistem pendidikan penjajah ketika itu. Nilai dan sumber budaya Barat yang bercirikan intelektualisme, individualism, egoisme dan materalisme telah mempengaruhi diantara masyarakat elit Indonesia. Hanya dengan cara mengembalikan nilai-nilai Islam diyakini tujuan pendidikan Islam dapat dilaksanakan. Sebab tujuan pendidikan Islam itu tidak dapat dipisahkan daripada tujuan hidup. Sebagaimana dikatakan (Langgulung, 1986) bahwa pendidikan Islam bertujuan untuk memelihara kehidupan manusia.

Belanda pada masa itu berusaha dengan giat untuk memasukkan ide-ide sistem pendidikan Barat ke dalam jiwa bangsa Indonesia. Seperti yang dikatakan oleh seorang orientalis Snouck Hurgronje, bahwa pendidikan Barat dapat menjadi alat pencegah terbaik bagi bahaya yang mungkin datang dari suatu gerakan Pan Islam yang militan di Indonesia.

Pada dasarnya tujuan pendidikan Belanda pada saat itu untuk menyiapkan tenaga kerja yang dapat dibayar murah serta menyokong politik yang mereka gunakan. Landasan pendidikan yang diselenggarakan pemerintahan Hindia Belanda sebelum tahun 1900 menganut prinsip antara lain: 1) tidak menfokuskan pendidikan hanya pada salah satu agama tertentu saja, 2) mempersiapkan murid agar memiliki keterampilan untuk bisa mendapatkan pekerjaan demi kepentingan Belanda, 3) sistem pendidikan berkasta menurut perbedaan status sosial masyarakat khususnya yang ada di Pulau Jawa. Hal ini bertujuan untuk mencerdaskan suatu golongan elit untuk selanjutnaya digunakan bagi kepentingan atau keperluan politik dan ekonomi Belanda di Indonesia (BP3K, 1987). 
Melihat fenomena perkembangan pendidikan yang dilaksanakan ketika itu K.H. Ahmad Dahlan merasakan perlu adanya organisasi yang dapat meneruskan citacitanya dalam mengembangkan nilai-nilai secara umum dan pendidikan Islam secara khusus. Maka pada tanggal 18 November 1912 berdirilah organisasi yang diberi nama Muhammadiyah.

Dari fenomena di ataslah peneliti tertarik untuk mengangkat tema penelitian tentang pemikiran pendidikan K.H. Ahmad Dahlan, antara tradisionalis dan modernis. Di mana pada penelitian ini difokuskan pada tiga pembahasan yaitu: Riwayat Hidup dan Pendidikan K.H. Ahmad Dahlan, Latar Belakang Pemikirannya, dan Pemikiran Pendidikan K.H. Ahmad Dahlan, Antara Tradisional dan Modernis.

\section{METODE PENELITIAN}

Penelitian ini adalah penelitian sejarah dimana data diperoleh dari sejarah, seterusnya diuji, dan dianalisa secara kritis melalui rekaman dan peninggalan sejarah yang terpercaya (Gottschalk, 2009); (Barnadib, 1982). Penelitian ini menggali pemikiran K.H. Ahmad Dahlan tentang pendidikan tradisionalis dan modernis. Penelitian sejarah pendidikan tergolong penelitian sejarah sosial. Penelitian sejarah sosial mempunyai dua proses penyajian yaitu sinkronis dan diakronis, dimana penelitian ini menggunakan model sinkronis.

Peneliti sebagai instrumen utama berperan aktif mencari jejak sejarah pemikiran pendidikan K.H. Ahmad Dahlan. Seterusnya data tersebut diseleksi, dikelompokkan dan diinterpretasikan.

\section{HASIL DAN PEMBAHASAN}

Riwayat Hidup dan Pendidikan K.H. Ahmad Dahlan

Ahmad Dahlan yang pada waktu kecilnya bernama Muhammad Darwis, lahir pada 1285 (1868 M) di Kampung Kauman Yogyakarta, yang dikenal sebagai daerah dengan keislaman yang sangat kuat hingga saat ini. Ia adalah putra ketiga dari Kiyai Haji Abu Bakar bin Kiyai Haji Sulaiman yang merupakan salah seorang khatib di Masjid Kesultanan Yogyakarta (Salam, 1962). Silsilah keturunannya ialah; Muhammad Darwis (Ahmad Dahlan) bin Kiyai Haji Abu Bakar bin K.H. Sulaiman bin K.H. Murtada bin Kiyai Ilyas bin Demang Jurang Juru Kapindo bin Demang Jurang Juru Sapisan bin Maulana Sulaiman $\mathrm{Ki}$ Ageng Gribig (Jatinom) bin Maulana Ainul Yakin bin Maulana Iskak bin Maulana Malik Ibrahim Waliyullah.

K.H. Ahmad Dahlan menikah pada 1888 dengan Walidah binti K.H. Penghulu K.H. Fadzil. Dari pernikahannya dengan Nyai Dahlan - panggilan Walidah - ia memperoleh 6 anak, yaitu: Johanah, Siraj Dahlan, Siti Busro, Siti Aisyah, Zuharah, dan Irfan Dahlan.

Sesuai situasi pada waktu itu, secara formal KH. Ahmad Dahlan dapat dikatakan tidak pernah memperoleh pendidikan, hal ini di antaranya disebabkan sikap orang tua Islam pada waktu itu yang melarang anakanaknya untuk memasuki sekolah Gubernemen. Dengan demikian, cara pendidikan yang ditempuhnya adalah cara pendidikan yang bersifat tradisional dengan cara menemui ulama-ulama yang ada pada waktu itu untuk mempelajari ilmu pengetahuan daripada mereka. Sebagaimana dijelaskan Mulkhan (1990), beliau belajar beragam ilmu, di antaranya fiqh dari K.H. Muhammad Saleh, ilmu nahu kepada K.H. Muhsin. Seorang gurunya yang lain ialah K.H. Abdul Hamid. Pengetahuannya dalam ilmu falaq diperolehnya dari gurunya K.H. Raden Dahlan, seorang putra Kiyai Termas. Sedangkan pengetahuannya dalam ilmu hadis diperolehnya dari Kiyai Mahfud dan Syeikh Khayyat.

Menjadi tradisi pada waktu itu, bahwa sebelum ia mempelajari ilmu-ilmu sebagaimana tersebut di atas, ia mengawalinya dengan mempelajari Alquran dari Syeikh Amin dan Sayyid Bakri Satock. Disamping itu juga, ia belajar ilmu Pengobatan dan racun binatang dari Syeikh 
Hasan (Mulkhan, 1990). Alhasil, setiap kaum cerdik pandai dijadikannya sebagai guru, termasuk R. Ng. Sosro Soegondo Wedana Dwijosewoyo, dan Syeikh M. Amin Djambek dari Bukittinggi.

Dengan mempelajari berbagai macam ilmu yang ada, akhirnya menjadikan ia tumbuh dan berkembang sebagai seorang yang bijaksana dengan ketajaman pikiran serta menjadi pemuda yang visioner. Setelah usianya menginjak dewasa yaitu pada usia 22 tahun, ia berangkat untuk mengerjakan ibadah Haji ke Makkah. Ibadah itu dikerjakannya pada tahun $1890 \mathrm{M}$, kesempatan yang ada itu dipergunakannya untuk menuntut ilmu agama diantaranya kepada ulama Minangkabau bernama Syeikh Ahmad Khatib selama 3 tahun dalam 2 kali kedatangan. Kedatangan yang pertama ia hanya menetap di kota tersebut selama satu tahun sedangkan pada kunjungan yang kedua, yaitu pada tahun 1903 M ia menetap di kota tersebut selama dua tahun.

Ketika ia berada di kota suci itu pulalah, K.H. Baqir, salah seorang ulama dari Kauman mempertemukan Dahlan dengan Rasyid Rida, salah seorang murid dari Muhammad Abduh. Dari Rida, K.H. Ahmad Dahlan mendapatkan informasi tentang ideide pembaruan dari Muhammad Abduh (Hadikusuma: 64). Bahkan, menurut Mohamad Kamil Hj. Abdul Majid (1993: 185-186), setelah ia kembali ke Indonesia, ide pembaruan tersebut terus diperdalamnya dengan membaca buku-buku dan majalah, sehingga ide tersebut akhirnya diperkaya dari pemikiran Ibn Taimiyyah (1263-1328) dan Ibn al-Qayyim al-Jauziyyah (1292-1350 M). Dalam keterangan yang lain dikatakan, bahwa buku-buku para pemikir di atas dapat ditemui diantara sumber bacaannya (Salam, 1965: 43-44).

Cita-cita pembaruan telah mulai dihayatinya ketika pertama kali pulang dari Makkah. Langkah pertama untuk mewujudkan cita-citanya itu adalah ketika ia berusaha memperbaiki arah kiblat bagi orang yang mengerjakan salat di Masjid Kesultanan Yogya. Usahanya ini menemui hambatan karena mendapat tantangan yang sangat hebat dari para kyai yang ada pada waktu itu. Akhirnya untuk mewujudkan citacitanya itu ia dapat membangun langgar (surau) dan menentukan arah kiblat secara benar menurut metode yang diyakininya. Akan tetapi usahanya itu juga tidak disenangi oleh para kyai yang konservatif, sehingga penghulu para kyai yaitu K.H. Mohamad Halil memerintahkan supaya meruntuhkan suraunya itu (Noer, 1985).

Tantangan yang dihadapinya nyaris membuat Dahlan patah hati, dan mengambil keputusan untuk meninggalkan kota kelahirannya. Untunglah pada waktu itu ada seorang dari keluarganya yang berhasil menghalangi dan membujuknya, serta berjanji akan membuatkan sebuah surau yang baru dimana ia dapat mengajarkan dan mempraktekkan ajaran agama menurut keyakinannya di surau tersebut (Noer, 1985). Dengan adanya jaminan tersebut Dahlan mengurungkan niatnya, akhirnya pada tahun 1896, ia diangkat sebagai khatib menggantikan ayahnya. Hal ini sekaligus sebagai permulaan Ahmad Dahlan dikenal sebagai ulama. Disamping itu, berkat kejujuran kesungguhannya sebagai khatib, Dahlan pun diberi gelar ketib amin (khatib yang dipercaya) (Umar, 2009). Menurut Selamat, (1997), gelar ketib amin yang diberikan oleh Kesultanan Yogyakarta kepada Dahlan, diterimanya saat usia yang relatif muda yaitu sekitar 28 tahun.

Disebabkan Ahmad Dahlan bukan seorang penulis, maka hampir keseluruhan gagasan maupun ide-idenya disampaikan dalam bentuk lisan dan karya nyata. Dahlan juga mengabdikan diri sebagai guru di Kweekschool Yogyakarta, OSVIA Magelang disamping menjadi Khatib di Masjid Sultan ("Ensiklopedi Islam Indonesia," 2002). Ketika berusia empat puluh tahun (1909), Ahmad Dahlan membuat inovasi baru dalam berdakwah. Hal ini diwujudkan dengan memasuki kelompok Budi Utomodan berdakwah kepada mereka. Akhirnya, citacitanya tersebut terbukti, serta menyarankan Ahmad Dahlan mendirikan sebuah sekolah 
melalui organisasi yang permanen. Melalui organisasi diharapkan akan lahir pemikiran untuk membangun sistem pengajaran yang senantiasa up-to date. Di antara anggota Budi Utomo yang sangat menyokong adanya sekolah seperti ini adalah Mas Radji dan R. Sosrosugodo (Deliar Noer, 1985: 86). Dari penjelasan-penjelasan di atas maka dapatlah dipahami, bahwa K.H. Ahmad Dahlan adalah seseorang yang cepat bisa diterima oleh berbagai kalangan, baik dengan sesama khatib di Mesjid Kesultanan Yogya, serta dengan para pimpinan organisasi dan tokohtokoh agama lain seperti Kristen untuk saling bertukar pikiran.

Kepribadian yang sangat komplit ini membantu dalam mewujudkan cita-citanya, hingga akhirnya sebelum ia wafat dalam usia 55 tahun, yaitu pada 23 Februari 1923 M/7 Rajab 1340 H (Mukhan, 1990: 7), ia telah berhasil mendirikan sebuah organisasi yang bergerak dalam pendidikan di Yogyakarta, yaitu organisasi Muhammadiyah, pada 18 November 1912. Organisasi ini mempunyai maksud "menyebarkan pengajaran kanjeng Nabi Muhammad SAW kepada penduduk bumi putra", dan "memajukan hal agama Islam kepada anggota-anggotanya" ("Ensiklopedi Islam Indonesia," 2002). Untuk mewujudkan cita-cita tersebut, Muhammadiyah mendirikan lembagalembaga pendidikan, mengadakan pertemuan dan tabligh yang membahas tentang masalah-masalah Islam, mendirikan badan wakaf dan mesjid-mesjid serta publikasi ide dan gagasannya melalui buku, brosur, surat kabar dan majalah.

Latar Belakang Pemikiran K.H. Ahmad Dahlan tentang Pendidikan Islam di Indonesia

Perkembangan, pemikiran modern dalam dunia Islam pada awal abad 20 dilatar belakangi oleh kondisi politik dan sosial yang dihadapi umat Islam ketika itu. Berbagai macam ide yang muncul dari pemikiran para tokoh adalah dalam rangka menjawab tantangan zaman sesuai dengan situasi dan kondisi yang ada. Begitu juga halnya dengan K.H. Ahmad Dahlan, seorang tokoh yang dikenal sebagai pendiri organisasi Muhammadiyah ini, dengan gagasan-gagasannya telah mencoba untuk menjawab tantangan yang ada. Gagasangagasan K.H. Ahmad Dahlan tidaklah sederhana, apalagi jika dilihat dari tingkat perkembangan intelektual umat Islam Indonesia dalam kurun dasawarsa kedua dan ketiga abad 20, sebagai jawaban terhadap situasi yang dihadapi oleh umat Islam Indonesia yang telah dikungkung oleh penjajahan selama tiga setengah abad.

Dari sudut perpspektif Islam Dahlan melihat, bahwa ada beberapa gejala menonjol yang sedang menyelimuti umat Islam Indonesia pada waktu itu, gejala-gejala tersebut ialah: 1) kerusakan dalam bidang kepercayaan, 2) kebekuan dalam bidang hukum fiqh, 3) kemajuan zending Kristen dan misi Katolik, 4) kemunduran dalam pendidikan Islam. Keempat pokok permasalahan ini akan diuraikan latar belakangnya, namun aspek penekanannya lebih difokuskan kepada aspek pendidikan, karena sesuai dengan pokok pembahasan.

Dalam bidang akidah, sebelum agama Islam masuk ke Indonesia, penduduk Indonesia pada umumnya dan Pulau Jawa pada khususnya telah terdapat beberapa kepercayaan lama, seperti animism, dinamisme, Budhisme dan sebagainya. Terakhir adalah Hindu dengan kekuatan politiknya berhasil menanamkan unsur-unsur kebudayaannya khususnya ke dalam masyarakat Jawa, dan agama Hindu pula pernah menjadi agama resmi kerajaan, di antara kerajaan-kerajaan Hindu yang ada, maka kerajaan Mataram-lah yang paling kuat terkena pengaruh tersebut.

Sikap beragama seperti ini terjadi secara turun-temurun sebelum terjadinya proses Islamisasi. Sikap yang demikian ini masih tetap bertahan, apalagi berdasarkan keterangan sejarah bahwa agama Islam yang datang ke Indonesia mulanya adalah bercorak sufistik (tarekat/tasawuf), sedangkan tarekat menurut para ahli adalah ajaran tasawuf yang tidak murni, hal ini dikarenakan adanya unsur-unsur asing yang 
tidak islami. Kenyataan ini dikuatkan lagi dengan hasil pengamatan seorang ahli yang mengatakan bahwa muslim pertama di utara Pulau Jawa sangat dipengaruhi oleh ajaranajaran yang berbau mistik (Greef, 1976).

Ketika Islam datang ke Indonesia (khususnya Jawa) Islam berhadapan dengan kepercayaan dan kebudayaan lama yang telah diamalkan masyarakat dalam waktu yang lama. Strategi yang dilakukan para wali pada waktu itu adalah mengambil sikap toleransi dan beradaptasi dengan kebudayaan yang ada (Kodiran, 1982). Manifestasi dari hal ini, akhirnya melahirkan Islam dengan wajah tersendiri, sehingga Hamka (1983) dalam buku tasawufnya menyebutkan sebagai Islam yang memuja kuburan wali dan sebagainya. Bahkan Snouck Hurgronje (1913: 35-38) juga menggambarkan bahwa kepercayaan kepada kekuatan roh, karomah para wali dan peran dukun yang dapat mempengaruhi nasib seseorang masih lazim dalam kehidupan umat Islam diawal abad 20 tersebut.

Dalam bidang hukum fiqh, fanatisme terhadap suatu mazhab yaitu Mazhab Syafi' i telah mulai diwariskan dari satu generasi ke generasi berikutnya. Keunggulan mazhab Syafi'i dari mazhab-mazhab yang lainnya dalam penyiaran Islam di Indonesia memang tidak dinafikan, justru Sufi pertama yang datang ke Indonesia yaitu Maulana Burhanuddin yang berasal dari India adalah penganut Mazhab Syafi'i (Lubis, 1993), ditambah pula dengan para imigran Arab yang berasal dari Hadramaut yang datang ke Nusantara pada umumnya mereka penganut Mazhab Syafi'i, yaitu mazhab yang dianut oleh mayoritas muslim di Semenanjung Arabia sejak menyebarnya mazhab fiqh (Qadri, 1973).

Melalui perantaraan mereka inilah, mazhab figh khususnya mazhab Syafi'i menyebar ke dalam masyarakat, baik melalui sarana tulisan maupun lisan. Dengan melalui dua sarana ini pula, taklid yang berkembang dalam dunia Islam masuk ke dalam komunitas Muslim Nusantara. Oleh karena itu, tidaklah mengherankan sebagaimana yang dinyatakan Nasution (1975: 192), bahwa Islam yang datang dan berkembang di Indonesia belum mengantarkan penganutnya pada pemikiran yang rasional dan memiliki peradapan yang tinggi, tetapi Islam yang telah mengalami kemunduran dengan pemikiran tradisional dan corak tarekat dan fiqhnya.

Dari sisi yang lain pula Pemerintah Hindia Belanda memegang kekuasaan yang menentukan segala-galanya. Sebagaimana dinyatakan Tim Pembina al-Islam dan Kemuhammdiyahan Universitas Negeri Malang (1990) bahwa agama Pemerintah Belanda, menurut resminya, adalah Protestan. Tentu saja dengan sendirinya tidak menghendaki kehadiran Islam.

Strategi politik pemerintah Hindia Belanda tidak hanya terbatas pada aspek sosial budaya, akan tetapi juga mengembangkan dan memanfaatkan misionaris Kristen yang diharapkan dapat menjadi pengganti rakyat (Mulkan: 133), karena itu dukungan yang besar dari Pemerintah Belanda terhadap kegiatan gerakanan Kristenisasi merupakan asset yang sangat besar berkembangnya agama Nasrani.

Dari uraian di atas dapat dipahami bahwa betapa kompleksnya permasalahan yang dihadapi oleh umat Islam Indonesia pada awal abad ke-20. Baik masalah agama, sosial dan politik menyatu menjadi satu. Hal inilah yang menjadi motivasi bagi K.H. Ahmad Dahlan untuk membersihkan ajaran Islam dari berbagai pengaruh dan berbagai kebiasaan yang bukan Islam; memformulasi kembali doktrin Islam agar sesuai menurut pikiran modern; mengadakan reformasi terhadap ajaran dan pendidikan Islam; mempertahankan Islam dari pengaruh serangan dari luar; dan melepaskan Indonesia dari belenggu penjajahan.

Khusus tentang masalah pendidikan, pemikiran K.H. Ahmad Dahlan dalam hal ini juga dilatar belakangi oleh beberapa faktor. Di antaranya adalah faktor yang ada di dalam Islam itu sendiri. Sebagaimana diketahui bahwa pendidikan Islam telah melalui berbagai situasi dan keadaan, di mana unsur- 
unsur budaya yang dominan di Negaranegara Islam atau Negara yang penduduknya mayoritas Islam menghadapi perubahan sosial-budaya, sehingga tuntutan terhadap berbagai macam keperluan tidak dapat dielakkan, memaksa umat Islam untuk mengikuti perubahan sesuai dengan tuntutan zaman.

Begitu juga halnya dengan keadaan pendidikan Islam di Indonesia. Jauh sebelum kolonial Belanda datang ke Indonesia, lembaga pendidikan Islam telah menyebar luas, yaitu sebagaimana yang dikenal dengan nama pondok pesantren. Pondok pesantren merupakan lembaga pendidikan tingkat menengah dan tingkat tinggi, di mana untuk tingkat permulaan pendidikan Islam diberikan di masjid, langgar atau surau. Di pondok pesantren siswa atau biasa disebut "santri" bebas untuk memilih bidang pelajaran dan guru yang diinginkannya, karena pada umumnya di samping kyai ada beberapa santri senior yang diberikan kepercayaan untuk mengajar. Sistem yang digunakan ada dua macam yaitu sistem sorongan dan sistem bandongan atau weton (Shabir, 1990). Di pesantren tidak ada pengkelasan, ujian sebagai evaluasi kemampuan santri juga tidak ada, dan batasan waktu santri harus tinggal di pondok juga tidak ditentukan alias bebas. Sistem pembelajaran menggunakan metode hafalan, Cabang ilmu yang diajarkan terbatas pada ilmu-ilmu agama. Sistem seperti ini terus bertahan hingga awal abad ke-20 (Shabir, 1990).

Di samping itu, jika dibandingkan dengan lembaga-lembaga kemasyarakatan secara luas, maka kelihatannya bahwa yang menjawab tuntutan-tuntutan dari masyarakat bukanlah lembaga pendidikan seperti pesantren. Mereka yang berada dalam lingkungan pesantren memperlihatkan kenyataan rendah diri dalam menghadapi peranan-peranan yang dilakukan oleh para dokter, insinyur, ahli hukum, pendidik, politisi atau tentara yang kebanyakan dilahirkan dari pendidikan modern. Pesantren ternyata di luar garis yang diperhitungkan dalam rencana-rencana nasional, bahkan masyarakat pada umumnya melihat letak dunia pesantren dalam lokasi terbelakang (Rahardjo, 1985). Sifat isolatif dari dunia pesantren ini juga dikarenakan oleh sistem organisasi yang ada di lembaga tersebut yang terlalu bergantung kepada selera kyai.

Dengan ciri-cirinya yang khas itu dunia pesantren masih berada dalam tawanan tradisinya yang sama sekali tidak peka terhadap masalah zaman dan lingkungannya yang menghidangkan masalah-masalah baru, ditambah lagi pimpinan pesantren dan para kyai tidak bersikap responsif terhadap gagasan-gagasan yang diajukan kepada mereka (Rahardjo, 1985).

Di pihak lain, pendidikan kolonial yang dirancang untuk kepentingan kelestarian kolonialisme di bumi Indonesia, sudah barang tentu bersumber dari nilai budaya Barat yang dilandasi oleh pandangan hidup yang bercirikan intelektualisme, individualisme, egoisme dan materialism. Pendidikan ini dimaksudkan untuk anakanak bumiputera. Pada awal abad ke-20 pendidikan guru dan sekolah kejuruan khususnya telah menyebar di beberapa kota, mulai dari pendidikan dasar sampai ke tingkat atas (Nasution, 1983).

Tujuan yang ingin dicapai oleh Pemerintah Hindia Belanda dari pendidikan adalah lahirnya golongan pribumi terdidik, yang memiliki kebudayaan Barat (Westernisasi). Hal ini merupakan salah satu politik Etis Pemerintah Belanda dari tahun 1900-1920 M, sebagai balasan atas keuntungan material yang mereka peroleh dari Indonesia. Politik ini menonjolkan kewajiban moral bangsa Belanda yang mereka anggap mempunyai kebudayaan tinggi terhadap Negara yang mereka jajah (Nasution, 1983).

Usaha Westernisasi ini tampaknya tidak berjalan sendiri, akan tetapi diiringi oleh usaha lain, yaitu kristenisasi dengan politik yang disebut kerstenings politek (Suminto, 1986). Akhirnya dari lembaga yang dikelola oleh Pemerintah Hindia Belanda ini 
melahirkan cendikia muslim yang cenderung tidak menghormati agamanya sendiri, mengkerdilkan tradisi leluhur dan memuja Barat.

Pemikiran Pendidikan K.H. Ahmad Dahlan, Antara Tradisional dan Modernis

Dalam pembahasan di atas telah dijelaskan, bahwa organisasi Muhammadiyah yang dipelopori oleh K.H. Ahmad Dahlan lahir karena terpanggil oleh suatu fenomena betapa menyedihkan dan rendahnya mutu pendidikan Islam dan kehidupan sosial umat Islam ketika itu. Pendidikan Islam khususnya di Indonesia pada awal abad 20, masih dalam keadaan tidak memperhatikan ilmu pengetahuan secara utuh.

Ahmad Dahlan bertekad pendidikan dapat mengisi kemampuan kognitif dan psikomotor yang diperlukan dalam kehidupannya nanti. Pendidikan yang ideal itu seyogyanya sesuai dengan kebutuhan masyarakat tempat mereka nantinya hidup (Umar, 2009). Ahmad Dahlan system pendidikan tradisionalis yang menjalankan pembelajaran yang diwarisi tanpa mencoba melihat relevansinya dengan perkembangan zaman. Padahal, menurut Dahlan, Alquran dan hadis meliputi berbagai materi, bukan hanya materi agama tapi juga berkaitan dengan dinamika kehidupan. Sebagaimana dikatakan Mulkhan (1990) materi Alquran dan hadist meliputi: ibadah, persamaan derajat, penciptaan manusia, nasib manusia, anjuran bermusyawarah, pembuktian kebenaran Alquran dan Hadis menurut akal, kerjasama antara agama-kebudayaankemajuan peradaban, hukum kausalitas perubahan, nafsu dan kehendak, demokratisasi dan liberalisasi, kemerdekaan berpikir, dinamika kehidupan dan peranan manusia di dalamnya, dan akhlak (budi pekerti).

Berdasarkan pemikiran tersebut, Ahmad Dahlan merupakan sosok pemuda yang menggunakan pendekatan self corrective terhadap umat Islam. Pandangan Muslim tradisionalis selalu fokus pada aspek spiritual dalam kehidupan sehari-hari saja. Sikap seperti ini bisa mengekang kemajuan dikalangan umat muslimin, bahkan cenderung mengakibatkan kemunduran baik dibidang ekonomi, teknologi dan lain-lain. Ahmad Dahlan terobsesi dengan kekuatan sistem pendidikan Barat terutama pandangannya tentang dunia dan kemajuankemajuan yang dialaminya. Ahmad Dahlan berpandangan bahwa kemajuan materil merupakan prioritas karena dengan itu kesejahteraan mereka akan bisa sejajar dengan kaum kolonial.

Upaya mewujudkan visi, misi dan tujuan pendidikan tersebut dilaksanakan lebih lanjut melalui organisasi Muhammadiyah yang didirikannya. Salah satu bidang atau program unggulan organisasi ini adalah bidang pendidikan. Madrasah yang pertama didirikan bertepatan pada tahun 1911. Madrasah ini berawal dari rumah Ahmad Dahlan, dimana beliau sendiri sebagai guru agama yang diharapkan bisa membekali kaum Muslimin terhadap pendidikan agama. Pelajaran selain agama disampaikan oleh anggota Budi Utomo yang berprofesi sebagai guru disekolah pemerintah.

Pada tahap awal, Madrasah ini belum banyak diminati masyarakat, terbukti hanya diiukti oleh 9 orang santri. Hal ini ini mungkin disebabkan oleh kurangnya pengetahuan masyarakat ketika itu tentang manfaat ilmu pengetahuan umum. Anggapan sebagian besar masyarakat muslim adalah bahwa ilmu pengetahuan umum adalah ilmu Belanda yang dikenal sebagai bangsa yang tidak beriman kepada Allah SWT atau kafir. Dengan kata lain, mendalami ilmu tersebut dikhawatirkan menjerumuskan generasi atau anak-anak mereka pada paham orang kafir yang bertentangan dengan agama islam.

Ahmad Dahlan merasa tidak puas dengan sistem pendidikan yang dualistis, yaitu sistem pendidikan Barat yang lebih mengembangkan aspek intelektual dan sistem pendidikan Islam yang kurang memperhatikan pengembangan aspek intelektual tersebut. Pendidikan Barat diterapkan secara intensif sesudah tahun 1900 di bawah panji-panji politik etis. 
Pendidikan ini membuka kesempatan yang lebih luas bagi anak golongan elite Indonesia dan golongan menengah untuk mendapatkan pendidikan yang lebih baik. Dengan jenis dan jenjang pendidikan yang bervariasi, sebagian mereka berhasil menjadi kaum intelektual ang memegang posisi penting dalam pemerintahan. Perluasan pendidikan inilah, seperti kata Neil (1984) yang menjadi akar perubahan sosial yang terjadi dalam masyarakat yang mempengaruhi elit Indonesia. Kalau sebelumnya kedudukan tinggi dalam hierarki kepegawaian ditentukan oleh keturunan dan kebangsawanan, maka kini pendidikan turut menjadi hal yang dipertimbangan, bahkan pada saat tertentu bisa menentukan yang diambil.

Dari satu sisi pendidikan Barat berjasa mengangkat generasi muda ke tingkat pendidikan tinggi dan memasukkan mereka ke dalam golongan intelektual. Tetapi dari sisi lain dengan corak pendidikan sekuler, umumnya membuat umat muslim bersikap negatif terhadap agama lain dan membuat jarak sosial kelompok sosial lainnya. Disamping itu, lembaga pendidikan Islam tetap bercirikan pendidikan yang khusus, Bahkan pelajaran masih terpusat pada bukubuku lama dengan metode pembelajaran konvensional yang belum banyak berubah sejak lembaga pendidikan itu didirikan.

Ahmad Dahlan memberikan penilaian yang berimbang terhadap ilmu dan kebudayaan Barat, tanpa mengurangi nilai yang tinggi kepada lembaga-lembaga pendidikan Islam walaupun masih bersifat tradisional. Agaknya keinginan untuk mengkompromikan segi-segi positif dari kedua jenis pendidikan itulah, di samping untuk mengatasi jenis kesenjangan sosial yang terjadi dalam masyarakat. Ahmad Dahlan mencetuskan ide-ide dan pemikirannya, yang kemudian menjadi sebagian dari sistem pendidikan Muhammadiyah. Di antara pemikirannya tersebut adalah menjadikan ilmu agama sebagai salah satu pelajaran yang wajib dalam lembaga pendidikan Barat sekaligus sistemnya ditetapkan dalam lembaga pendidikan agama (Lubis, 1993).

Dalam rangka mengimplementasikan gagasan dan ide-ide pembaruan dalam pendidikan, ia selanjutnya membangun lembaga pendidikan yang modern namun masih menggunakan sistem klasikal. Hal ini merupakan salah satu langkah yang cukup unik dan kurang lazim diterapkan oleh lembaga pendidikan islam pada waktu itu, yaitu dengan mengabungkan kedua sistem tersebut (sistem pendidikan Belanda dan pendidikan tradisional) secara integral (Steenbrink, 1986).

Hal ini pun masih mendapat tanggapan yang belum maksimal dari masyarakat. Kondisi ini, tidak membuat Ahmad Dahlan putus asa. Berbagai cara dilakukan agar jumlah siswa yang mengikuti pendidikan semakin banyak, mulai dari mengumpulkan dana dan mengunjungi anak-anak sampai ke rumahnya. Usaha ini sangat berhasil meningkatkan jumlah santri menjadi 20 santri dalam 6 bulan. Anggota-anggota Budi Utomo, juga membantu mendekati pemerintah untuk mendapatkan suntikan keuangan. Usaha ini pun berhasil mendapat bantuan karena sekolah yang dikelola Muhammadiyah ini dinilai pemerintah memenuhi syarat telah ikut mewujudkan tugas pemerintah (Poerbakawatja, 1970). Selanjutnya berdiri juga Madrasah Diniyah Islamiyah (1 Desember 1911), dengan konsentrasi mempelajari ilmu-ilmu pengetahuan umum (Taruna, S., \& Ismatu Ropi, 2002).

Pada tanggal 18 November 1912 (8 Dzulhijjah $1330 \mathrm{H})$ resmilah berdirinya Muhammadiyah. Hal ini semakin membuat semakin banyaknya berdiri sekolah baru serta semakin tumbuhnya kesadaran masyarakat akan pentingnya ilmu pengetahuan umum. Diantara sekolahsekolah baru tersebut adalah sekolah di Karangkajen, Lempuyangan dan Pasargede yang secara berturut-turut berdiri pada tahun 1913, 1915, dan 1916. Pada tahun 1920, akibat meningkatnya jumlah siswa, Madrasah Diniyah Islamiyah dipindah ke 
Suronatan. Di Suronatan ini, dikhususkan untuk putra saja, sedangkan di Kauman masih ditempati oleh siswa perempuan. Menariknya, sekolah Muhamaddiyah yang menekuni ilmu umum ini sudah setara dengan volk schools atau sekolah rakyat.

Meningkatnya jumlah santri secara tidak langsung menuntut adanya jumlah guru yang berimbang. Untuk itu Muhammadiyah perlu mendirikan sekolah guru (1918) yang disebut Qism al-Aqra di rumah Ahmad Dahlan. Sekolah yang menerima lulusan volk school atau yang memiliki latar pendidikan untuk dididik mengajarkan pendidikan agama dan bahasa Arab. Wiryosukarto (1962: 122-123) dalam penelitiannya menyebutkan bahwa pelajaran yang diberikan di sekolah menengah Qism al-Aqra sebagai pendidikan menengah tingkat perama adalah sebagai berikut: (1) Alquran dan Hadis; (2) Bukubuku fiqh dari Mazhab Syafi'I; (3) Ilmu tasawuf karya Imam al-Ghazali; (4) Ilmu kalam yang ditulis oleh para ulama ahlussunnah ditambah dengan buku Risalah al-Tauhid karya Muhammad Abduh; (5) Buku Tafsir Jalalain dan al-Manar.

Pelajaran umum yang diajarkan meliputi: (1) Ilmu sejarah; (2) Ilmu hitung; (3) Menggambar; (4) Bahasa Melayu; (5) Bahasa Belanda; (6) Bahasa Inggris. Keenam mata pelajaran tersebut diajarkan secara bersamaan, dengan artian materi ilmu sejarah diberikan di kelas A selama waktu yang ditetapkan, sementara mata pelajaran lain juga diberikan dikelas yang berbeda. Tambahan lagi, sistem evaluasi telah menerapkan istilah ulangan harian, dan daftar kehadiran murid telah menjadi sebuah tagihan dalam nilai akhir siswa serta telah dikenal sistem kenaikan kelas (Wiryosukarto, 1962).

Dari segi cara pelaksanaan pendidikannya sudah tidak menggunakan Mesjid dan Surau sebagai tempat belajar, namun sudah seperti ruang kelas yang ada sekarang ini. Waktu belajar permanen dilaksanakan pada siang hari. Murid tidak lagi hanya menerima apa yang tertulis dalam buku yang dipelajari, akan tetapi dituntut mampu mengkritisi dan membandingkan, buku fiqh yang mengajarkan pendapat mujtahid tertentu (Wiryosukarto, 1962). Murid-murid juga dituntut memiliki bukubuku pelajaran dimana hasil belajar masingmasing ditentukan melalui ujian yang bertingkat sampai mereka dinyatakan lulus atau tamat dan mendapatkan ijazah atau diploma (Jainaru, 1990).

Perbedaan yang lainnya yaitu hubungan antara guru dengan murid di lembaga pendidikan yang didirikan oleh K.H. Ahmad Dahlan ini bersifat terbuka dan demokratis. Guru tidak dianggap sebagai seorang yang mempunyai keramat, akan tetapi dihormati secara wajar (Wiryosukarto, 1962). Muridmurid perempuan juga diberi kesempatan untuk belajar bersama murid laki-laki dalam satu kelas.

Gagasan pembaruan terhadap tenaga pengajar atau guru dilakukan dengan mengangkat guru-guru yang mempunyai kualifikasi ilmu-ilmu agama. Langkah ini, akhirnya mengantarkan pada kondisi dimana Muhammadiyah memiliki sumber daya guru yang memiliki latar belakang pesantren, dan pendidikan sekolah guru pemerintah serta guru dari alumni sekolah guru Muhammadiyah.

Dengan demikian, sistem pendidikan yang dipelopori oleh K.H. Ahmad Dahlan merupakan suatu model pembaruan yang merupakan integrasi antara sistem dan unsur lama dengan yang baru. Hal ini dimaksudkan bahwa, unsur lama tetap dipertahankan seperti agama Islam sebagai asas, sedangkan unsur-unsur baru seperti model dan strategi pemebelajaran diadopsi dari sistem Barat. Dalam pengertian lain, pembaruan pendidikan yang dipelopori oleh K.H. Ahmad Dahlan adalah untuk mewujudkan sebuah peradaban universal yang lahir dari ketegangan zikir dan pikir. Peradaban seperti inilah yang ingin ditawarkan oleh K.H. Ahmad Dahlan, sebagai alternatif bagi masa depan umat Islam Indonesia. 


\section{KESIMPULAN DAN REKOMENDASI}

Sejalan dengan masuknya Islam di Indonesia dan berdirinya kerajaan-kerajaan Islam, maka pendidikan Islam telah mulai dilaksanakan, yang lebih dikenal dengan nama pondok pesantren. Sistem yang digunakan dibagi ke dalam dua yaitu sistem sorongan dan sistem bandongan atau weton. Di pondok pesantren santri tidak dibedakan dalam kelas, tidak ada ujian untuk evaluasi, dan batasan waktu belajar juga tidak ditetapkan serta cabang ilmu pengetahuan yang diajarkan hanya terbatas pada ilmuilmu agama.

Di sisi lain, pendidikan Islam pada zaman penjajahan sangat tidak menguntungkan, apalagi hakikatnya penjajah khususnya Hindia Belanda tidak menyukai jika pendidikan Islam berkembang dengan baik. Di samping itu, jika dibandingkan pula dengan lembaga pendidikan lainnya seperti yang didirikan oleh pihak penjajah ternyata dunia pesantren menempati posisi terbelakang dalam berbagai bidang. Keadaan yang demikian ini bertambah parah, khususnya bagi perkembangan pendidikan Islam di Indonesia karena tujuan pendidikan yang ingin dicapai oleh pihak penjajah (Hindia Belanda) disamping menginginkan sumber daya manuasia pribumi yang intelek, namun juga berkebudayaan Barat (westernisasi), yang berhubungan dengan Kristenisasi.

Permasalahan-permasalahan yang demikian itu merupakan motivasi bagi K.H. Ahmad Dahlan yang menerima pengaruh dari Mesir khususnya Muhammad Abduh untuk melakukan aktivitas pembaruan, di antaranya reformasi terhadap pengajaran dan pendidikan Islam di Indonesia. Dualisme pendidikan Islam pada waktu itu, masingmasingnya memiliki kesenjangan yaitu pertama lebih mengembangkan aspek intelektual (sistem pendidikan Barat) sehingga kosong dari aspek agama Islam. Kedua, lebih menonjolkan tentang aspek agama saja dan sangat minim memperhatikan aspek intelektual. Dari dua jenis pendidikan itu, K.H. Ahmad Dahlan tidak melihat salah satunya, akan tetapi ia melihat segi-segi positifnya dan memberikan penilaian yang tinggi kepada keduanya, baik ilmu dan kebudayaan Barat dan ilmu-ilmu agama dalam lembaga-lembaga pendidikan Islam tradisional (Pesantren)

\section{REFERENSI}

Barnadib, I. (1982). Arti dan Metode Sejarah Pendidikan. Yogyakarta: Yayasan Penerbitan FIP-IKIP.

BP3K. (1987). Pendidikan di Indonesia. Jakarta: T.P.

Ensiklopedi Islam Indonesia. (2002). Jakarta: Djambatan.

Gottschalk, L. (2009). Mengerti sejarah. Terjemahan Nugroho Notosusanto. Jakarta: UI-Press.

Greef, H. J. D. (1976). Islamic States in Java 1500-1700. Nijhoff: Hague Martinus.

Hamka. (1983). Tasawwuf, Perkembangan dan Pemurniannya. Jakarta: Panjimas.

Haviz, M., Karomah, H., Delfita, R., Umar, M., \& Maris, I. (2018). Revisiting Generic Science Skills as 21st Century Skills on Biology Learning. Jurnal Pendidikan IPA Indonesia, 7(3), 355363.

Jainaru, A. (1990). Muhammadiyah Gerakan Reformasi Islam di Jawa pada Awal Abad Kedua Puluh. Surabaya: Bina Ilmu.

Kodiran. (1982). Kebudayaan Jawa, dalam Kuntjaraningrat (ed.), Manusia dan Kebudayaan di Indonesia. Jakarta: Djambatan.

Langgulung, H. (1986). Manusia dan Pendidikan Suatu Analisis Psikologi dan Pendidikan. Jakarta: Pustaka Al Husna.

Lubis, A. (1993). Pemikiran Muhammadiyah dan Muhammad Abduh Suatu Studi Perbandingan. Jakarta: Bulan Bintang.

Mulkhan, A. M. (1990). Pemikiran K.H. Ahmad Dahlan dam Muhammadiyah dalam Perspektif Peurbahan Sosial. Jakarta: Bumi Aksara. 
Nasution, S. (1983). Sejarah Pendidikan Indonesia. Bandung: Jemmars.

Neil, R. Van. (1984). Munculnya Elit Modern Indonesia, diterjemahkan oleh Zahara Deliar Noer. Jakarta: Pustaka Jaya.

Noer, D. (1985). Gerakan Modern Islam di Indonesia 1900-1942. Jakarta: LP3ES.

Poerbakawatja, S. (1970). Pendidikan dalam alam Indonesia merdeka. Jakarta: Gunung Agung.

Qadri, A. A. (1973). Islamic Yurisprudence in the Islamic World. Lahore: SH. Muhammad Ashraf.

Rahardjo, M. D. (1985). Pesantren dan Pembaruan. Jakarta: LP3ES.

Selamat, M. I. (1997). Pengaruh Pemikiran Kiyai Haji Ahmad Dahlan terhadap Perkembangan Pemikiran di Indonesia. Disertasi, Kuala Lumpur: Universiti Malaya.

Shabir, M. (1990). Muhammadiyah Kini \& Esok. Jakarta: Panjimas.

Steenbrink, K. A. (1986). Pesantren, Madrasah dam Sekolah Pendidikan Islam dalam Kurun Modern. Jakarta: LP3ES.
Suminto, A. (1986). Politik Hindia Belanda. Jakarta: LP3ES.

Taruna, S., D., \& Ismatu Ropi. (2002). Pranata Islam di Indonesia. Pergulatan Sosial, Politik, Hukum dan Pendidikan. Jakarta: Logos Wacana Ilmu.

Umar, B. (2009). Pemikiran Pendidikan Islam. Batusangkar: STAIN Batusangkar Press.

Umar, M. I. A., Yap, C. C., Awang, R., \& Salleh, M. M. (2017). Effect of thermal reduction temperature on the optical and electrical properties of multilayer graphene. J. Mater Sci-Mater. El., 28(1), 1038-1041.

Umar, M. I. A., Yap, C. C., Awang, R., Salleh, M. M., \& Yahaya, M. (2014). The effect of spin-coated polyethylene glycol on the electrical and optical properties of graphene film. Appl. Surf. Sci., 313, 883-887.

Wiryosukarto, A. H. (1962). Pembaruan Pendidikan dan Pengajaran Islam. Yogyakarta: T.P.

Yusuf, M. Y., \& Dkk. (1985). Citra dan Cita Muhammadiyah. Jakarta: Pustaka Panjimas.

\section{Article Metadata:}

Selamat, K. (2019). Between Traditionalist and Modernist: Educational Thoughts of K.H. Ahmad Dahlan. Ta'dib, 22 (2), 75-86.

http://dx.doi.org/10.31958/jt.v22i2.1637

Keywords: K.H. Ahmad Dahlan, Education systems, Islamic World

Coresponding author: Kasmuri Selamat, IAIN Batusangkar, kasmuriselamat31@ gmail.com 